\title{
Rotational Grazing Effects on Rangeland Vegetation at a Farm Scale
}

\author{
Elizabeth J. Jacobo, Adriana M. Rodríguez, Norberto Bartoloni, \\ and Victor A. Deregibus
}

Authors are Professors, Departamento de Producción Animal, Facultad de Agronomia, Universidad de Buenos Aires, Argentina.

\begin{abstract}
We evaluated the adequacy of rotational grazing to improve rangeland condition in the Flooding Pampa region, eastern Argentina, comparing the floristic composition dynamic of the 2 main plant communities under rotational and continuous grazing over a study period of 4 years (1993-1996). The experiment was conducted in commercial farms located in 4 sites of the Flooding Pampa region. In each site, a couple of farms, one managed under rotational grazing (implemented in 1989) and an adjacent one managed under continuous grazing at a similar stocking rate $\left(1 \mathrm{AU} \cdot \mathrm{ha}^{-1}\right)$, constituted the replications of the experiment. Basal cover of species, litter, and bare soil were monitored in midslope and lowland grassland communities on each farm. Total plant basal cover in midslope and in lowland communities remained unchanged over the whole experimental period under both grazing methods. Under rotational grazing, litter cover was higher in both communities while the amount of bare soil showed a significant reduction in lowlands and a tendency to be lower in midslope. Basal cover of legumes, $\mathrm{C}_{3}$ annual and $\mathrm{C}_{3}$ perennial grasses was higher, while cover of $\mathrm{C}_{4}$ prostrate grasses was lower under rotational grazing in the midslope community. In the lowland community, rotational grazing effects were evident only in the drier years, when higher cover of hydrophytic grasses and legumes and lower cover of forbs occurred. Plant species diversity did not change in response to grazing. In conclusion, rotational grazing promoted functional groups composed of high forage value species and reduced bare soil through the accumulation of litter. These changes indicate an improvement in rangeland condition and in carrying capacity. As the stocking rate was approximately $60 \%$ higher than the average stocking rate of the Flooding Pampa region, we believe that productivity and sustainability may be compatible by replacing continuous with rotational grazing.
\end{abstract}

\section{Resumen}

Para evaluar si el pastoreo rotativo permite mejorar la condición de los pastizales de la Pampa Inundable, ubicada al este de Argentina, se comparó durante 4 años (1993 a 1996) la composición florística de las dos principales comunidades vegetales sometidas a pastoreo rotativo o continuo. El experimento se llevó a cabo en establecimientos agropecuarios ubicados en 4 localidades, donde se seleccionaron dos establecimientos, uno manejado con pastoreo rotativo (desde 1989) y otro adyacente manejado con pastoreo continuo, ambos con similares cargas $\left(1 \mathrm{UA} \cdot \mathrm{ha}^{-1}\right)$. Se relevó la cobertura basal de las especies, de broza y de suelo desnudo en las comunidades de media loma y de bajo dulce en cada establecimiento. La cobertura basal total de ambas comunidades no se modificó durante el período de estudio bajo ambos sistemas de pastoreo. Bajo pastoreo rotativo, el suelo cubierto por broza fue mayor mientras que el suelo desnudo fue menor en los bajos y mostró una tendencia a disminuir en las medias lomas. En la media loma, la cobertura de leguminosas, de gramíneas invernales anuales y perennes aumentó y la cobertura de gramíneas estivales rastreras disminuyó. En el bajo dulce, el efecto del pastoreo rotativo sólo se manifestó en los años secos cuando aumentó la cobertura de gramíneas hidrófitas y de leguminosas y disminuyó la de malezas. La diversidad florística no varió como consecuencia del sistema de pastoreo. El pastoreo rotativo promovió grupos florísticos de alto valor forrajero y redujo el suelo desnudo mediante la acumulación de broza. Estos cambios indican una mejora en la condición del pastizal y en su capacidad de carga. Como la carga utilizada en este sistema fue un $60 \%$ superior a la carga promedio de la región, concluimos que es posible compatibilizar los objetivos productivos y la sustentabilidad de estos pastizales mediante el pastoreo rotativo.

Key Words: grazing systems, plant community structure, plant diversity, temperate grasslands

\section{INTRODUCTION}

The impact of grazing on community structure and ecosystem functioning is a key issue for range management in order to

This research was funded by the National Council of Research Argentina (CONICET).

Correspondence: Elizabeth J. Jacobo, Dept de Producción Animal, Facultad de Agronomía, Universidad de Buenos Aires, Av. San Martin 4453 (C1417DSE), Buenos Aires, Argentina. Email: ejacobo@agro.uba.ar

Manuscript received 31 July 2005; manuscript accepted 26 January 2006. maximize livestock production and sustainability of the operations. In the short term, grazing can influence the structure of plant communities by removing plant tissues and, in the long term, by changing botanical composition and species diversity through selective grazing. Overgrazing of temperate grassland typically decreases tall grasses and more palatable species (Crawley 1983) and increases prostrate grasses (Mitchley and Grubb 1986), annuals (Mack 1989), and forbs (Bullock et al. 1994). Although excessive grazing may often lead to land degradation and loss of biodiversity, maximization of livestock production requires maintaining high stocking rates because 
this variable determines the potential magnitude of profits realized by a ranching enterprise (Conner 1991). However, stocking rate is the main factor affecting quantity, quality, and vegetation composition of rangelands (Heitschmidt et al. 1987; Gillen et al. 1998; Hickman et al. 2004).

Grazing systems are management tools, which allow range managers to control the frequency and duration of grazing and rest periods to optimize livestock and plant performance (Heitschmidt and Taylor 1991). Rotational grazing systems have been claimed to increase carrying capacity through improving range condition (Savory and Parsons 1980). Even though these systems have allowed improving stocking rate (Heitschmidt et al. 1987) most available data about their impact on vegetation shows no benefits (Hart et al. 1988; Hickman et al. 2004) or deleterious effects (Thurow et al. 1988; Taylor et al. 1993; Taylor et al. 1997).

In Flooding Pampa rangelands, continuous grazing has led to the replacement of native perennial grasses, which dominated in the pristine vegetation, by annuals and forbs, both natives and exotics of Eurasian origin (Sala et al. 1986; Facelli 1988). Continuous grazing has also caused a severe reduction of cool season grasses, which are highly preferred by cattle during winter (Agnusdei 1991; Deregibus et al. 1995) and the increase of species richness due to the invasion of exotic species, lowgrowing native forbs and prostrated grasses (Rusch and Oesterheld 1997). These changes are clearly indicative of rangeland degradation (Deregibus and Cahuépé 1983), including decreased net primary production (Rusch and Oesterheld 1997) and forage quality (Chaneton et al. 1988). Results of a recent study in the Flooding Pampa region (Jacobo et al. 2000) showed that applying rotational grazing in association with higher stocking rates increased productivity of a winter grass of high forage value, suggesting that this system may help increase range condition and animal production in this region. While the economic advantage of such management has been shown (Deregibus et al. 1995), the effect of rotational grazing on grassland community composition and biodiversity is not fully known.

The aim of this study was to evaluate the adequacy of rotational grazing as a management tool to improve rangeland condition in Flooding Pampa grassland. In doing so, we compared the dynamic of the two main plant communities under rotational and continuous grazing over a study period of 4 years. Our specific objectives were to study the responses of 1) functional groups, 2) litter and bare soil, and 3) species diversity when rotational grazing was implemented.

\section{METHODS}

\section{Study area}

The Flooding Pampa, a $90000 \mathrm{~km}^{2}$ region of grasslands, is located in the Province of Buenos Aires, between lat $35^{\circ}-38^{\circ} \mathrm{S}$, long $57^{\circ}-63^{\circ} \mathrm{W}$ in eastern Argentina (Soriano et al. 1991). Angus and Hereford cow/calf operations are the main economic activity. This grassland had been continuously grazed at an annual stocking rate of $0.6 \mathrm{AU} \cdot \mathrm{ha}^{-1}$ for the last century. The average secondary production is $70 \mathrm{~kg}$ meat ha ${ }^{-1}$ year $^{-1}$.

The regional climate is temperate sub-humid with mean annual precipitation varying from 1000 in the north to $850 \mathrm{~mm}$ in the south evenly distributed throughout the year. Monthly temperatures range from $6.8^{\circ} \mathrm{C}$ in July-August to $21.8^{\circ} \mathrm{C}$ in January. Because of the flat relief and the occurrence of a high water table, most soils belong to the halo-hydromorphic complexes and associations influenced by flooding (Natraquols, Natracualfs, Natralbols, and Argialbols). Well-drained soils (Hapludols and Argiudols) are restricted to the upland landscape areas where pastures and crops are cultivated. Vegetation is arranged in a complex mosaic of herbaceous communities mainly determined by landscape features (subtle topography and soil salinity gradient), while latitudinal (regional) variation plays a secondary role (Perelman et al. 2001). The two most extended plant communities (around $70 \%$ of native grassland) occupy the midslope and lowland areas and therefore are affected by different flooding regimes. They are dominated by different grass species with contrasting tolerance to soil water logging (Chaneton et al. 2002), and were found to respond differently to grazing and environmental variation (Chaneton 2005). The midslope community is dominated by Paspalum dilatatum Poir, Bothriochloa laguroides (DC) Herter, Sporobolus indicus (L) R.Br., Panicum milioides Nees ex Trin., Lolium multiflorum Lam, Stipa neesiana Trin. \& Rupr., Briza subaristata Lam., Piptochaetium montevidensis (Spreng.) Parodi, and Danthonia montevidensis Hack. \& Arechav. The lowland community is dominated by Paspalidium paludivagum (Hitchc. \& Chase) Parodi, Leersia hexandra Sw, Chaetotropis elongata (Knut) Björkman, Alternanthera philoxeroides (Mart.) Griseb., Mentha pulegium L., and Leontodon taraxacoides (Vill.) Mérat.

\section{Experimental design}

In order to achieve a wider scope of vegetation responses to grazing management, farms located in four sites of the Flooding Pampa (Verónica, Vieytes, Rauch, and General Alvear) were selected. Sites were treated as blocks. In each farm, midslope and lowland communities were analyzed separately because they respond differently to disturbances like flooding or grazing (Chaneton 2005). Consequently, two similar and simultaneous experiments were conducted, one in midslope and another in lowland community.

At each site, two adjacent farms were selected, one managed under continuous grazing and the other under rotational grazing since March 1989, when continuous grazing method was replaced by rotational grazing. Four paddocks with a predominance of midslope community and another four paddocks with a predominance of lowland community were selected in each farm, with the exception of Vieytes, where lowland community was not assessed because it was poorly represented in this area. As each community is clearly associated with topographic position and soil attributes (Perelman et al. 2001), these features were used as criteria for paddock selection. None of the paddocks had ever been treated with any agricultural practice (fertilization, inter-sowing, etc.). The experiment was run for 4 years (from 1993 to 1996 ) and the allocation of the paddocks was not changed throughout the experimental period. General Alvear assessment was interrupted in 1995 because rotational grazing in the commercial farm was discontinued.

\section{Annual rainfall and seasonal distribution}

Annual rainfall during the first two years (1993 and 1994) was above the long-term mean for the region, in particular in 1993, an extremely rainy year during autumn and spring. Conversely, 


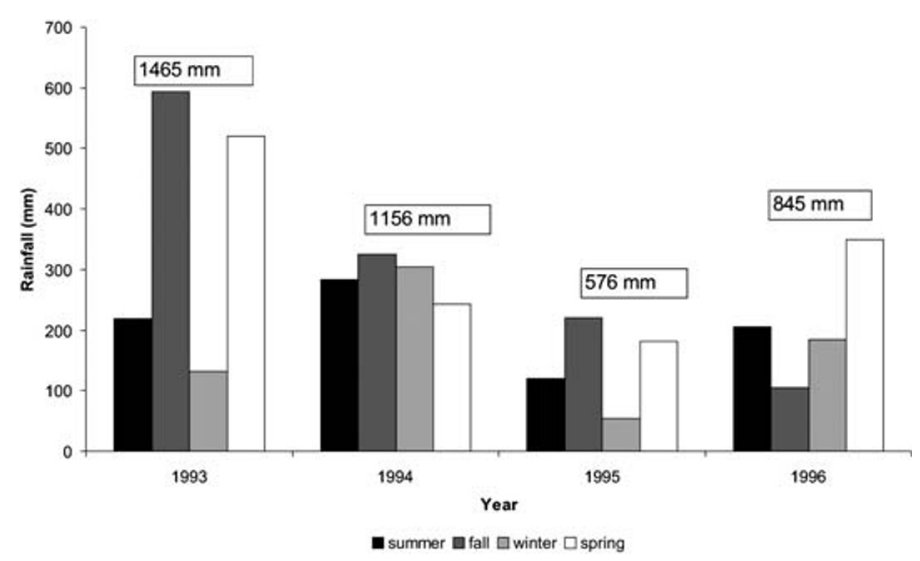

Figure 1. Seasonal rainfall distribution at the experimental sites during the study period. Seasonal mean rainfall (1961-2001) for summer is $285 \mathrm{~mm}$, for fall is $205 \mathrm{~mm}$, for winter is $185 \mathrm{~mm}$ and for spring is $260 \mathrm{~mm}$. Data were provided by Servicio Meteorológico Nacional weather stations Punta Indio, Castelli, and Las Flores.

annual rainfall of the last two years (1995 and 1996) was below the mean value, due to an extremely dry period between summer 1995 and winter 1996 (Fig. 1).

\section{Grazing treatments}

Rotational grazing was performed by concentrating herds of 400 to 500 breeding cows (Angus and Hereford), which sequentially grazed a series of 10-12 paddocks with an average size of $45 \mathrm{ha}$. The average weight of cows was $420 \mathrm{~kg}$. The breeding season ran from November to January and calves were weaned during April (6-8 month of age) with an average weight of $170 \mathrm{~kg}$. Since the physiological status of herds changed throughout the year, the stocking rate gradually increased from $0.8 \mathrm{AU} \cdot \mathrm{ha}^{-1}$ in winter (from May to July) to $1.2 \mathrm{AU} \cdot \mathrm{ha}^{-1}$ in March. Consequently, the annual average stocking rate was $1 \mathrm{AU} \cdot \mathrm{ha}^{-1}$. This represented a stock increase of approximately $60 \%$ compared to the average stocking rate of the Flooding Pampa region. The occupation period in each paddock varied between 3 to 15 days and the rest period between 25 to 90 days according to the growth rate of major forage species. During autumn and winter nearly all the available biomass was removed in each grazing event, while during spring and summer only around $50 \%$ of the available biomass was grazed to allow cattle forage selection in order to improve body condition for breeding. The stocking rate of continuously grazed paddocks was equal to the average stocking rate of rotational grazed ones $\left(1 \mathrm{AU} \cdot \mathrm{ha}^{-1}\right)$ in order to avoid confusion between the effect of stocking rate and that of grazing method.

\section{Sampling and data arrangement}

Vegetation was monitored in spring (November-December) of 1993, 1994, 1995, and 1996, during the peak season of primary production (Sala et al. 1981; Paruelo et al. 2000). Plant basal cover and species composition were estimated using the steppoint method (Mueller-Dombois and Ellenberg 1974) along five 10-m-long transects (200 points per transect) randomly placed in each paddock. Bare soil, litter, or standing dead material was recorded where no living plants were intercepted.

Plant species were classified considering a hierarchical approach (Lavorel et al. 1997) according to growth form, life history, photosynthetic pathway, morphology, and symbiotic nitrogen fixation, to obtain functional groups. The functional group approach has been used to study grazing effects in the Flooding Pampa grasslands (Facelli et al. 1989; Hidalgo and Cahuépé 1991; Rusch and Oesterheld 1997). This approach allows the comparison among communities of different areas, which can be floristically different but constituted by the same functional groups. The emergent functional groups were: $\mathrm{C}_{3}$ annual grasses; $\mathrm{C}_{3}$ perennial grasses; $\mathrm{C}_{4}$ tussock grasses; $\mathrm{C}_{4}$ prostrate grasses; hydrophytic grasses; sedges, forbs, and legumes. As most forbs species respond to grazing in a similar way (Díaz et al. 2001) no distinction was made regarding their life history and phenology. Relative cover (\%) was calculated from total basal cover, including litter, bare soil, and standing dead material.

\section{Statistical analysis}

Two main effects, grazing method and year, and their interaction were examined. Multivariate Analysis of Variance (MANOVA) techniques (Seber 1984) were used to test overall differences taking into account the correlations among response variables. Analysis of Variance (ANOVA) techniques were used to evaluate differences on each response variable. As most variables (cover of functional groups, dead material, litter, and bare soil) showed lack of normality, they were rank transformed (Huberty 1994). Data of paddocks inside each farm was averaged in order to obtain the values that were analyzed.

A complete repeated measures ANOVA was not performed because of the lack of sufficient amount of data (as it was mentioned former, lowland community was only assessed in three sites and one site assessment was interrupted in 1995). Notwithstanding, to account for the possible covariance among measures over years, the independence hypotheses have been tested in case of full data. In order to know if the repeated measures in the same paddock violated the ANOVA independence assumption, Mauchley's sphericity tests were carried out on all the response variables and none were statistically significant. In addition, Huynh-Feldt conditions were checked and found correct (Huynh and Feldt 1970; Jennrich and Schuchter 1986).

For each sampling date, the Shannon-Wiener Index, $\mathrm{H}^{\prime}$ (Zar 1984) was calculated to determine the effect of grazing method and year on plant species diversity. ANOVA was used to test the significance of difference between $\mathrm{H}^{\prime}$.

\section{RESULTS}

\section{Plant communities composition, litter, and bare soil}

Almost no variables were statistically different among block means. As sites constituted the blocks for the statistical analysis, the lack of statistical differences among blocks shows a remarkable homogeneity among sites.

In the midslope community, overall floristic differences between grazing method and year tested by MANOVA showed significant differences (grazing method $P=0.000074$, year $P=0.009$ ). Total plant basal cover of midslope community (average $71 \%$ ) was not affected either by grazing method or by annual variation. However, grazing method strongly affected the presence of most functional groups (Table 1). Basal cover 
of legumes, $\mathrm{C}_{3}$ annual grasses, and $\mathrm{C}_{3}$ perennial grasses was higher, while cover of $\mathrm{C}_{4}$ prostrate grasses was lower under rotational grazing (Figs. 2a, b, c, e). The other functional groups did not respond to the grazing method (Figs. 2d, f, g). The cover of litter increased under rotational grazing (Fig. 2i). Inter-annual variation strongly affected $\mathrm{C}_{4}$ tussock grasses, which showed a tendency to decrease as the years became drier (Fig. 2d). Cover of litter and standing dead material were lower in the driest year (Figs. 2h, i). No interaction between grazing method and year was detected for any of the structural variables (Table 1).

In the lowland community, overall floristic differences tested by MANOVA only showed significant differences for year effect (grazing method $P=0.181$, year $P=0.007$ ). Total plant basal cover of lowland community (average 66\%) was not affected either by grazing method or annual variation. However, rotational grazing significantly increased the cover of hydrophytic grasses (Fig. 3b) and decreased the cover of forbs (Fig. 3e), while the other functional groups were not affected by the grazing method (Figs. 3a, c, d, f) (Table 2). In this community, rotational stocking increased litter cover (Fig. 3h) and reduced bare soil (Fig. 3i). Legumes, $\mathrm{C}_{4}$ tussock grasses, and sedges were affected by inter-annual variation (Table 2 ). Sedges tended to decrease as the years became drier (Fig. 3f), while the cover of legumes increased in the same period, especially under rotational grazing (Fig. 3a). No interaction effects between grazing method and year were detected for any structural variable (Table 2).

\section{Species diversity}

Plant species diversity, which was higher for the midslope community than for the lowland one, did not change either among years $\left(\mathrm{H}^{\prime}\right.$ shown in Table 3 were the average of the different years) or after 8 years of implementing a different grazing method in both communities.

\section{DISCUSSION}

\section{Plant communities composition}

The most attractive aspect of time-controlled grazing systems to livestock producers is the higher stocking rates that can be used (Heitschmidt et al. 1987; Jacobo et al. 2000), because of more intensive management resulting from the subdivision of large pastures and the addition of water sources (Hart et al. 1993). Difficulty in maintaining high stocking rates under continuous grazing for any extended period of time (Heitschmidt et al. 1983) has led to initial experiments to evaluate rotational grazing systems at stocking rates higher than those used in continuous grazing. However, maximization of livestock production requires maintaining high stocking rates because this variable determines the potential magnitude of profits realized by a ranching enterprise (Conner 1991). Therefore, in this study we compared both grazing systems at a stocking rate of $1 \mathrm{AU} \cdot \mathrm{ha}^{-1}$, which economic profits have already been demonstrated (Deregibus et al. 1995). This represented a stock increase of approximately $60 \%$ compared to the average stocking rate of the Flooding Pampa region $\left(0.6 \mathrm{AU} \cdot \mathrm{ha}^{-1}\right)$.

Intensive time-controlled grazing systems have been claimed to improve range condition and forage production because the control of the frequency and duration of grazing and nongrazing periods allows beneficial plants to recover from being
Table 1. ANOVA $P$ and $F$ values for the effects of Grazing Method, Year, and their interaction on different structural variables in the midslope community. Main effects and interactions were considered significant at $P<0.05$ and are shown in bold type.

\begin{tabular}{|c|c|c|c|c|c|c|}
\hline & \multicolumn{2}{|c|}{ Grazing method } & \multicolumn{2}{|c|}{ Year } & \multicolumn{2}{|c|}{$\begin{array}{c}\text { Grazing } \\
\text { method } \times \text { Year }\end{array}$} \\
\hline & $P$ & $F(1,21)$ & $P$ & $F(3,21)$ & $P$ & $F(3,21)$ \\
\hline Legumes & 0.005 & 9.628 & 0.859 & 0.252 & 0.314 & 1.257 \\
\hline $\mathrm{C}_{3}$ annual grasses & 0.008 & 8.337 & 0.665 & 0.547 & 0.610 & 0.619 \\
\hline $\mathrm{C}_{3}$ perennial grasses & 0.013 & 7.208 & 0.561 & 0.702 & 0.525 & 0.766 \\
\hline $\mathrm{C}_{4}$ tussock grasses & 0.080 & 3.257 & 0.004 & 7.020 & 0.942 & 0.128 \\
\hline $\mathrm{C}_{4}$ prostrate grasses & 0.047 & 4.897 & 0.181 & 1.780 & 0.958 & 0.101 \\
\hline Forbs & 0.942 & 0.005 & 0.960 & 0.097 & 0.895 & 0.199 \\
\hline Sedges & 0.913 & 0.012 & 0.468 & 0.877 & 0.715 & 0.456 \\
\hline Litter & $<0.001$ & 36.840 & $<0.001$ & 11.316 & 0.491 & 0.831 \\
\hline Bare soil & 0.079 & 3.382 & 0.204 & 1.669 & 0.749 & 0.411 \\
\hline Dead material & 0.364 & 0.851 & 0.003 & 6.068 & 0.555 & 0.711 \\
\hline
\end{tabular}

severely bitten and avoids repeated selective grazing of preferred plants (Savory 1983). The results of this experiment support this claim because rotational grazing promoted functional groups composed of high forage value species (winter annual and perennial grasses, hydrophytic grasses, and legumes). Simultaneously, rotational grazing decreased functional groups composed of less valuable forage species (summer prostrate grasses) and groups composed of species without forage value, like forbs. As vegetation composition is used as an indicator of range condition, we believe that these vegetation changes can be considered an improvement of Flooding Pampa rangelands. Nevertheless, the benefits of time-controlled grazing systems are supported by very little direct and some indirect evidence, but most research refutes them. Hart et al. (1988) found that different grazing systems and stocking rates didn't affect botanical composition of a mixed prairie. Dormaar et al. (1997) found no difference between botanical composition of a rotational grazed mixed prairie and the exclosure and Gillen et al. (1991) found very little difference between rotational grazed tallgrass prairie and exclosure at different stocking rates, showing the resilience of these communities. Other authors found that vegetation responses to grazing systems may be strongly dependent on or over-ridden by effects of stocking rate because stocking rate is more important than grazing systems on affecting plant community structure (Gammon and Roberts 1978; Thurow et al. 1988; Gillen et al. 1998; Hickman et al. 2004). However, other authors found that rotational grazing allows the increase of stocking rate compared to continuous grazing with very little effect on the vegetation (Pitts and Bryant 1987; White et al. 1991).

In time-controlled grazing systems, the length of rest period can change vegetation response. Whereas Ralphs et al. (1990) and Taylor et al. (1997) found that fixed rest periods of 51 days deteriorate vegetation from moderate to heavy stocking rate, Taylor et al. (1993) found that longer rest periods promote secondary succession. Rotation in our study never followed a fixed schedule, but according to forage supply and plant growth rate in order to avoid overgrazing of some paddocks and undergrazing of the others. In late spring, when higher growth rate occurs, the rest period was around 25 days and it 

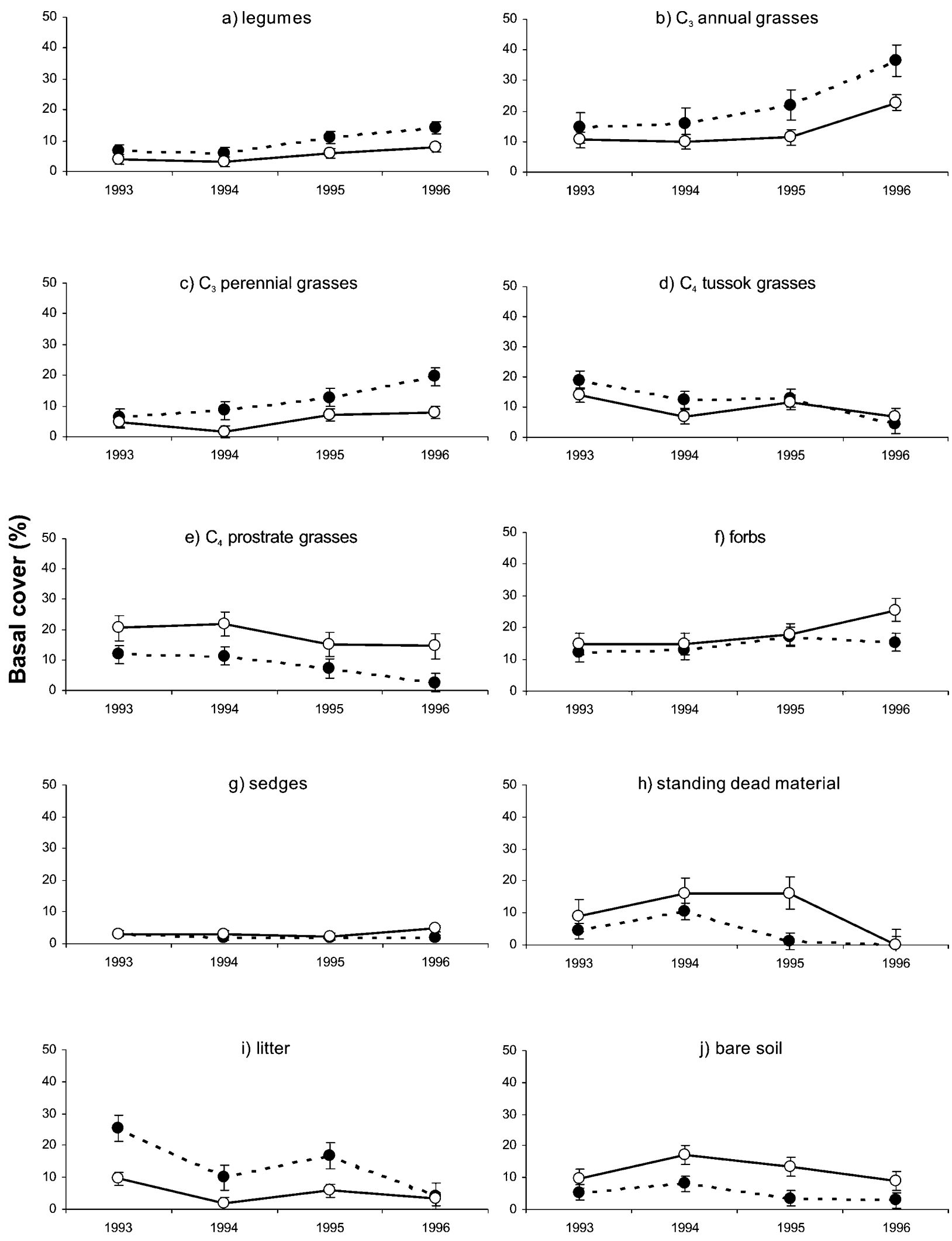

\section{Year}

Figure 2. Basal cover of functional groups, standing dead material, litter, and bare soil of the midslope community. Continuous grazing (solid line). Rotational grazing (dotted line). Bars indicate standard errors. Observations were made in spring. 

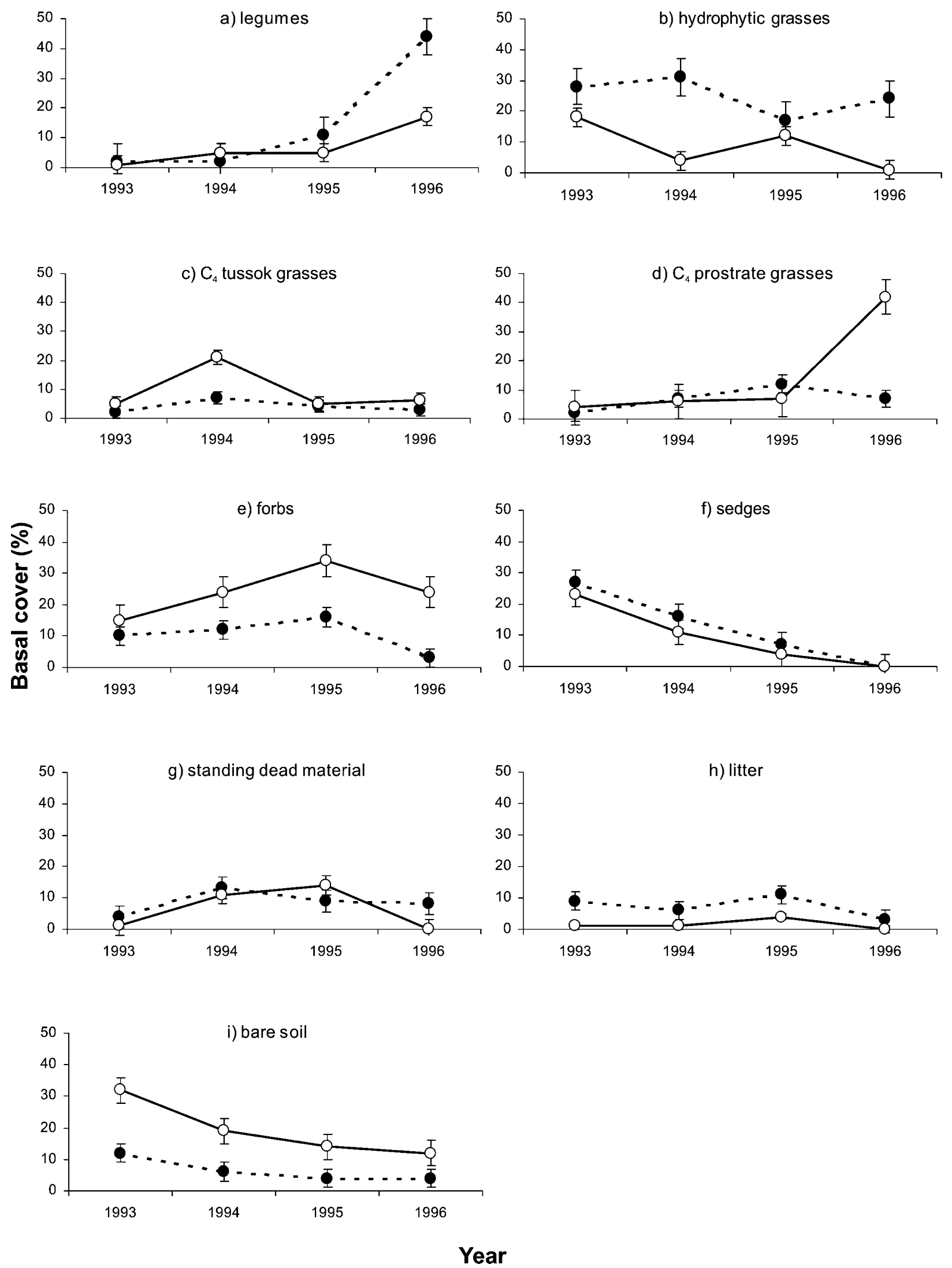

Figure 3. Basal cover of functional groups, standing dead material, litter, and bare soil of the lowland community. Continuous grazing (solid line). Rotational grazing (dotted line). Bars indicate standard errors. Observations were made in spring. 
Table 2. ANOVA $P$ and $F$ values for the effects of Grazing Method, Year, and their interaction on different structural variables in lowland community. Main effects and interactions were considered significant at $P<0.05$ and are shown in bold type.

\begin{tabular}{|c|c|c|c|c|c|c|}
\hline & \multicolumn{2}{|c|}{ Grazing method } & \multicolumn{2}{|c|}{ Year } & \multicolumn{2}{|c|}{$\begin{array}{c}\text { Grazing } \\
\text { method } \times \text { Year }\end{array}$} \\
\hline & $P$ & $F(1,10)$ & $P$ & $F(3,10)$ & $P$ & $F(3,10)$ \\
\hline Legumes & 0.711 & 0.145 & 0.014 & 5.801 & 0.223 & 1.730 \\
\hline Hydrophitic grasses & 0.006 & 11.729 & 0.403 & 1.073 & 0.190 & 1.918 \\
\hline $\mathrm{C}_{4}$ tussock grasses & 0.137 & 2.612 & 0.041 & 4.011 & 0.511 & 0.821 \\
\hline $\mathrm{C}_{4}$ prostrate grasses & 0.329 & 1.049 & 0.330 & 1.289 & 0.386 & 1.119 \\
\hline Forbs & 0.020 & 7.483 & 0.374 & 1.154 & 0.352 & 1.219 \\
\hline Sedges & 0.503 & 0.480 & 0.011 & 6.223 & 0.974 & 0.069 \\
\hline Dead material & 0.545 & 0.391 & 0.034 & 4.276 & 0.472 & 0.899 \\
\hline Litter & 0.002 & 16.845 & 0.134 & 2.340 & 0.908 & 0.178 \\
\hline Bare soil & 0.014 & 8.623 & 0.331 & 1.287 & 0.939 & 0.130 \\
\hline
\end{tabular}

increased progressively as growth rate decreased, until around 90 days in winter.

Total plant basal cover remained unchanged along the 4 years of the study, in spite of the wide rainfall fluctuation. The stability in plant cover of these communities during a period of large environmental fluctuations was already reported by Chaneton (2005); it contrasts with the response of semiarid grasslands, in which total plant cover was related to rainfall during the growing season (Lauenroth and Sala 1992).

Impact of rotational grazing in Flooding Pampa was strongly community-specific. In midslopes, where plant community is codominated by $\mathrm{C}_{3}$ (winter) and $\mathrm{C}_{4}$ (summer) grasses, rotational grazing increased the cover of $\mathrm{C}_{3}$ grasses (both annual and perennial) and legumes, major contributors to palatable forage. Winter annual grasses, a key functional group because it contributes during the winter forage shortage, was made up by almost $80 \%$ Lolium multiflorum Lam. Seed germination and establishment of this species is promoted by direct light (Deregibus et al. 1994) generated by intensive defoliation under rotational grazing in early autumn, when soil moisture and temperature allow the onset of germination (Rodríguez et al. 1998). Such development of winter species cover under rotational grazing might have caused the reduction of $\mathrm{C}_{4}$ prostrate grasses considering that during spring, the high biomass productivity of winter grasses (Jacobo et al. 2000) may have depleted nutrients or over-topped summer prostrate grasses prior to the start of their growing period. However, the variation in grazing methodology didn't affect the basal cover of summer tussock grasses in midslope, in spite of the high palatability of the main component of this group, Paspalum dilatatum (Lemcoff et al. 1978). This suggests that there was not overgrazing of these species under continuous grazing, probably due to a) the higher aboveground productivity of this group during summer, $31 \mathrm{~kg} \mathrm{DM} \cdot \mathrm{ha}^{-1} \cdot \mathrm{d}^{-1}$ (Sala et al. 1981) respect to stocking rate $\left(1 \mathrm{UA} \cdot \mathrm{ha}^{-1}\right)$ and b) herbivore preference for lowland community in summer (Agnusdei 1991). Summer tussock grasses, which vegetate when growing conditions are dry, showed a lower proportion at the end of the experimental period, probably affected by 1995 summer drought, an extremely dry year $(576 \mathrm{~mm})$. It is known that midslope ecotypes of $P$. dilatatum are highly sensitive to water stress (Loreti and
Table 3. Mean Shannon-Wiener diversity index $\left(\mathrm{H}^{\prime}\right)$ in midslope and lowland communities of Flooding Pampa grassland under continuous and rotational grazing. $\mathrm{H}^{\prime}$ shown were the average of different years.

\begin{tabular}{lcc}
\hline & $\begin{array}{c}\text { Midslope community } \\
\mathrm{H}^{\prime}\end{array}$ & Lowland community \\
\hline Continuous grazing & 3.06 & $\mathrm{H}^{\prime}$ \\
Rotational grazing & 3.18 & 2.61 \\
$P$ & 0.65 & 2.45 \\
\hline
\end{tabular}

Oesterheld 1996) and the germination and survival of plants are strongly controlled by soil water content and duration of wet period (Cornaglia 2002).

In lowland community, grazing effects were not evident during wet years. Normally as water saturation of soils occurs during several months, hydrophytic grasses and sedges dominate this community. In 1993, an extremely rainy year, plant community was dominated by sedges ( $25 \%$ cover) irrespective of the grazing method while forbs represented only $13 \%$, probably because most of them are intolerant to soil oxygen deficiency prevailing during flooding periods (Insausti et al. 1999). As years became drier, sedges decreased and plant community followed different pathways depending on grazing management: a) under continuous grazing summer prostrate grasses and forbs replaced sedges, whereas b) under rotational grazing, hydrophytic grasses maintained an important cover even during dry years and legumes tended to increase towards the end of the experimental period. Grazing responses in the lowland community were significant only in the drier years, supporting previous claims from Chaneton (2005), who reported that grazing effect on plant composition was inversely related to annual rainfall. The rapid changes in plant composition observed in the lowland community, probably associated with inter-annual rainfall variation, contrast with the inertia of semiarid grasslands (Lauenroth and Sala 1992).

\section{Litter cover and bare soil}

Litter cover under rotational grazing was higher than under continuous grazing; consequently, bare soil showed a significant reduction in lowlands and a tendency to be lower in midslopes when rotational grazing was applied. The increment of litter cover may be a consequence of the higher animal density under rotational grazing (up to $10 \mathrm{AU} \cdot \mathrm{ha}^{-1}$ ), which removes the standing dead material accumulated during spring-summer, the period of highest productivity (Sala et al. 1981). Litter, through soil temperature buffering and soil moisture conservation, affects the plant microclimate, an aspect of particular importance in summer when atmospheric demand is high (Hall et al. 1992). We believe that this result is further evidence of range condition improvement due to rotational grazing, because litter accumulation could improve soil conditions (Dormaar et al. 1997). Other studies showed no difference in litter cover among grazing systems heavily stocked (Hart et al. 1988; Taylor 1993; Weltz and Wood 1986), or between heavily rotational grazing and moderately continuous grazing (White et al. 1991).

\section{Species diversity}

These grasslands, originally dominated by $\mathrm{C}_{3}$ and $\mathrm{C}_{4}$ tall grasses, were drastically modified by the introduction of domestic 
European cattle in the 15th century (Deregibus 1988). This caused the invasion of alien forbs, which increased species richness (Sala et al. 1986; Chaneton and Facelli 1991) but drastically reduced aboveground net primary productivity (Rusch and Oesterheld 1997). In lowland, invasion is restricted to a few exotic species able to tolerate direct physical stress as consequence of frequent soil water logging, causing low values of $\mathrm{H}^{\prime}$ compared to midslope communities (Perelman et al. 2001). When grazing is excluded, a rapid reduction in forbs cover occurs due to competition from tall grasses, so species richness and $\mathrm{H}^{\prime}$ decrease (Rusch and Oesterheld 1997). Replacing continuous with rotational grazing didn't change $\mathrm{H}^{\prime}$ in any of the communities. Although cover of native and exotic forbs decreased under rotational grazing, the concomitant increase of exotics of high forage value species like L. multiflorum and Lotus tenuis resulted in no significant changes in plant species diversity. This response has been reported for other temperate grasslands, where the increase of some species under heavy grazing were counteracted by the decrease of others (Bullock et al. 2001), and differ from those of arid environments, where heavy grazing tends to decrease grassland richness (Landsberg et al. 2003).

\section{Implications for livestock management}

Although the introduction of domestic European cattle in the 15 th century modified floristic composition and structure of these grasslands (Deregibus 1988), this process accelerated drastically since the end of the 19th century, when cattle became confined and therefore continuous grazing initiated (Deregibus et al. 1995). Traditional continuous grazing has deteriorated these grasslands, leading to 1) severe reduction of winter grasses which are highly preferred and severely defoliated during winter, 2) invasion by exotic and native forbs of low forage value, 3) soil denudation, 4) reduction of carrying capacity, animal performance, and net profitability (Deregibus et al. 1995).

The application of rotational grazing has usually resulted in an immediate increase of the stocking rate of about $30 \%$, as a consequence of the better distribution of animals and utilization of the residual forage. The conception rate (around $89 \%$ ) and the proportion of weaned calves (around 95\%) have been high in spite of the higher stocking rate implemented. Consequently, meat production increased from 66.4 to 105.2 $\mathrm{kg} \cdot \mathrm{ha}^{-1} \cdot \mathrm{y}^{-1}$ after continuous grazing was replaced by rotational grazing (Deregibus et al. 1995).

The structural changes registered in this study such as the increase of functional groups composed of high forage value species, the decline of forages of lower value species, and the reduction of bare soil through the accumulation of litter indicate an improvement in rangeland condition and in carrying capacity. This is partially due to the increase of winter forage productivity (Jacobo et al. 2000), allowing further increments of stocking rate reaching at least that implemented in our study. In conclusion, we assess that it is possible to achieve a sustainable utilization of the Flooding Pampa grassland by replacing continuous with rotational grazing, in agreement with Holechek et al. (1998), who asserted that short duration grazing works best in flat humid areas that have extended growing season.

A remarkable feature of this grazing system was its flexibility, based on the understanding of the biological processes involved, in contrast to other rigid rotational systems that apply occupation periods of a fixed number of days. In our system, the occupation and rest periods varied throughout the year depending on the growing rate of the dominant grasses. The grazing intensity also varied following particular objectives, such as the promotion of germination of winter annual grasses through high grazing intensity in autumn, or the increment of cattle body weight just before breeding season through lenient grazing during spring.

Another feature of our study that adds to its value is that the experimental replicates were individual farms rather than small plots. Therefore, recommendations for grazing management that arise from this study are based on a relevant operational scale.

\section{ACKNOWLEDGMENTS}

We are grateful to Enrique Chaneton, Rodolfo Golluscio, and 2 anonymous reviewers for their recommendations, which greatly improved an earlier draft of this manuscript. We also thank Martín Garbulsky for helping with data collection.

\section{LITERATURE CITED}

Agnusdel, M. G. 1991. Análisis de gradientes en suelos de áreas bajas de la Depresión del Salado [thesis]. Mar del Plata, Argentina: Facultad de Ciencias Agrarias, Universidad Nacional de Mar del Plata. $109 \mathrm{p}$

Bullock, J. M., B. Clear Hill, M. P. Dale, and J. Silvertown. 1994. An experimental study of vegetation change due to sheep grazing in a species-poor grassland and the role of seedling recruitment into gaps. Journal of Applied Ecology $31: 493-507$

Bullock, J. M., J. Franklin, M. J. Stevenson, J. Silvertown, S. J. Coulson, S. J. GREGORY, AND R. Tofts. 2001. A plant trait analysis of responses to grazing in a long-term experiment. Journal of Applied Ecology 38:253-267.

Chaneton, E. J. 2005. Impacto de las perturbaciones naturales sobre los ecosistemas: las inundaciones en pastizales pampeanos. Ciencia Hoy (in press).

Chaneton, E., and J. M. Facelli. 1991. Disturbance effects on plant community diversity: spatial scales and dominance hierarchies. Vegetatio 93:143-155.

Chaneton, E., J. M. Facelli and R. J. C. León. 1988. Floristic changes induced by flooding on grazed and ungrazed lowland grasslands in Argentina. Journal of Range Management 41:495-499.

Chaneton, E., S. Perelman, M. Omacini, and R. J. C. León. 2002. Grazing, environmental heterogeneity and alien plant invasion in temperate Pampa grasslands. Biological Invasions 4:7-24.

ConneR, J. R. 1991. Social and economic influences on grazing management. In: R. K. Heitschmidt and J. W. Stuth [EDS.]. Grazing management. An ecological perspective. Portland, OR: Timber Press. p 191-199.

Cornaglia, P. 2002. Paspalum dilatatum: germinación y establecimiento de pastizales naturales [thesis]. Buenos Aires, Argentina: Escuela para Graduados, Facultad de Agronomía, UBA. 105 p.

Crawley, M. J. 1983. Herbivory: The dynamics of plant-animal interactions. Oxford, United Kingdom: Blackwell Scientific Publications. 437 p.

Deregibus, V. A. 1988. Importancia de los pastizales naturales en la República Argentina: situación presente y futura. Revista Argentina de Producción Animal 8:67-78.

Deregibus, V. A., And M. A. Cahuépé. 1983. Pastizales naturales de la Depresión del Salado: utilización basada en conceptos ecológicos. Revista de Investigaciones Agropecuarias 1:47-78.

Deregibus, V. A., J. J. Casal, E. J. Jacobo, D. Gibson, M. Kauffman, and A. M. RodRíGUEz. 1994. Evidence that heavy grazing might promotes the germination of Lolium multiflorum seeds via phytocrome mediated perception of high red-far red ratios. Functional Ecology 8:536-542.

Deregibus, V. A., E. J. JaCOBO, AND A. M. RodríGuez. 1995. Improvement in rangeland condition of the Flooding Pampa of Argentina through controlled grazing. African Journal of Range and Forage Science 12:92-96.

Díaz, S., I. Noy-MEIR, AND M. CABIDO. 2001. Can grazing response of herbaceous plants be predicted from simple vegetative traits? Journal of Applied Ecology 38:497-508. 
Dormaar, J. F., B. W. Adams, And W. D. Willms. 1997. Impacts of rotational grazing on mixed prairie soils and vegetation. Journal of Range Management 50:647-651.

FACELLI, J. M. 1988. Response to grazing after nine years of cattle exclusion in a flooding Pampa grassland, Argentina. Vegetatio 78:21-25.

Facell, J. M., R. J. C. León, and V. A. Deregibus. 1989. Community structure in grazed and ungrazed grasslands sites in the Flooding Pampa, Argentina. American Midland Naturalist 121:125-133.

Gammon, D. M., And R. B. Roberts. 1978. Patterns of defoliation during continuous and rotational grazing of the Matapos Sandveld in Rhodesia. 1. Selectivity of grazing. Rhodesian Journal of Agricultural Research 16:117-131.

Gillen, R. L., F. T. McCollum III, M. E. Hodges, J. E. Brummer, and K. W. Tate. 1991. Plant community responses to short duration grazing in tallgrass prairie. Journal of Range Management 44:124-128.

Gillen, R. L., F. T. McCollum III, K. W. Tate, and M. E. Hodges. 1998. Tallgrass prairie response to grazing system and stocking rate. Journal of Range Management 51:139-146.

Hall, A. J., C. M. Rebella, C. M. Ghersa, and J. Ph. Culto. 1992. Field-crop system of the Pampas. In: C. J. Pearson [eds.]. Field Crop Ecosystems. Amsterdam, London, N.Y., Tokyo: Elsevier. p 413-450.

Hart, R. H., J. Bissio, M. J. Samuel, and J. W. Waggoner, JR. 1993. Grazing systems, pasture size, and cattle grazing behavior, distribution and gains. Journal of Range Management 48:81-87.

HaRT, R. H., M. J. Samuel, P. S. Test, and M. A. Smith. 1988. Cattle, vegetation, and economic responses to grazing systems and grazing pressure. Journal of Range Management 41:282-286.

Heitschmidt, R. K., S. L. Dowhower, and J. W. Walker. 1987. Some effects of a rotational grazing treatment on quantity and quality of available forage and amount of ground litter. Journal of Range Management 40:318-321.

Heitschmidt, R. K., A. B. Johnson, J. R. Frasure, and D. L. Price. 1983. Cow-calf and vegetation response to heavy rates of stocking at the Texas Experimental Ranch. Texas Agricultural Experimental Station Bulletin 1427.

Heitschmidt, R. K., and C. A. TayloR, JR. 1991. Livestock Production. In: Grazing management: An Ecological Perspective. R. K. Heitschmidt and J. W. Stuth [EDS.]. Portland, OR: Timber Press. p 161-177.

Hickman, K. R., D. C. Hartnett, R. C. Cochran, and C. L. Owensby. 2004. Grazing management effects on plant species diversity in tallgrass prairie. Journal of Range Management 57:58-65.

Hidalgo, L. G., AND M. A. Cahuépé. 1991. Effects of seasonal rest in above ground biomass for a native grassland of the flood Pampa, Argentina. Journal of Range Management 44:471-475.

Holechek, J. L., R. D. Pieper, And C. H. Herbel. 1998. Range management principles and practices. Upper Saddle River, NJ: Prentice Hall. 542 p.

HuberTY, C. J. 1994. Applied Discriminant Analysis. New York, NY: Wiley Interscience. $446 \mathrm{p}$.

HuYnh, H., AND L. S. Feldt. 1970. Conditions under which mean square ratios in repeated measures designs have exact F-distributions. Journal of the American Statistical Association 65:1582-1589.

Insausti, P., E. J. Chaneton, and A. Soriano. 1999. Flooding reverted grazing effects on plant community structure in mesocosmos of lowland grassland. Oikos 84:266-276.

Jacobo, E. J., A. M. Rodríguez, J. L. Rossi, L. P. Salgado, and V. A. Deregibus. 2000. Rotational stocking and production of Italian ryegrass on Argentinian rangelands. Journal of Range Management 53:483-488.

JenNRICH, R. I., AND M. D. SCHUChTER. 1986. Unbalanced repeated-measures models with structured covariance matrices. Biometrics 42:805-820.

Landsberg, J., C. D. James, S. R. Morton, W. J. Muller, and J. Stol. 2003. Abundance and composition of plant species along grazing gradients in Australia rangelands. Journal of Applied Ecology 40:1008-1024.

Lauenroth, W. K., and O. E. Sala. 1992. Long-term forage production of North American shortgrass steppe. Ecological Applications 2:397-403.

Lavorel, S., S. Mclntyre, J. Landsberg, and T. D. A. Forbes. 1997. Plant functional classifications: from general groups to specific groups based on response to disturbance. Trends in Ecology and Evolution 12:474-478.
Lemcoff, J. H., O. E. Sala, V. A. Deregibus, R. J. C. León, and T. M. Schlichter. 1978. Preferencia de los vacunos por los distintos componentes de un pastizal de la Depresión del Salado. Monografías Comisión de Investigaciones Científicas 8:57-70.

LoReti, J., AND M. Oesterheld. 1996. Intraspecific variation in the resistance to flooding and drought in populations of Paspalum dilatatum from different topographic positions. Oecologia 108:279-284.

MAck, R. N. 1989. Temperate grasslands vulnerable to plan invasions: characteristic and consequences. In: J. A. Drake, H. A. Mooney, F. di Castri, R. H. Groves, F. J. Kruger, M. Rejmánck, and M. Williamson [eds.]. Biological invasions: a global perspective. Chichester: John Willey and Sons. p 155-179.

Mitchley, H., And P. J. GRubB. 1986. Control of relative abundance of perennial in chalk grasslands in southern England. 1. Constancy of rank order and results of pot and field experiments on the role of interference. Journal of Ecology 74:1139-1166.

Mueller-Dumbois, D., and H. Ellenberg. 1974. Aims and Methods of Vegetation Ecology. New York, NY: J. Willey and Sons. $547 \mathrm{p}$.

Paruelo, J. M., M. Oesterheld, C. M. Di Bella, M. Arzadum, J. Lafontaine, M. Cahuépé, and C. M. Rebella. 2000. Estimation of primary production of subhumid rangelands from remote sensing data. Applied Vegetation Science 3:185-195.

Perelman, S. B., R. J. C. León, and M. Oesterheld. 2001. Cross-scale vegetation patterns of flooding Pampa grasslands. Journal of Ecology 89:562-577.

Pitts, J. S., and F. C. Bryant. 1987. Steer and vegetation response to short duration and continuous grazing. Journal of Range Management 40:386-399.

Ralphs, M. H., M. M. Kothmann, and C. A. TayloR, JR. 1990. Vegetation response to increased stocking rates in short-duration grazing. Journal of Range Management 43:104-108.

Rodríguez, A. M., E. J. Jacobo, and V. A. DeregiBus. 1998. Germination behavior of Italian ryegrass in flooding Pampa rangelands. Seed Science Research 8:521-528.

Rusch, G. M., And M. Oesterheld. 1997. Relationship between productivity and species and functional group diversity in grazed and non-grazed Pampas grasslands. Oikos 78(3):519-526.

Sala, 0. E., V. A. Deregibus, T. M. Schlichter, and H. Alippe. 1981. Productivity dynamics of a native grassland in Argentine. Journal of Range Management 34:48-51.

Sala, O. E., M. Oesterheld, R. J. C. León, and A. Soriano. 1986. Grazing effects upon plant community structure in subhumid grasslands of Argentina. Vegetatio 67:27-32.

SAVORY, A. 1983. The Savory grazing methods or holistic resource management. Rangelands 5:155-159.

Savory, A., and S. D. Parsons. 1980. The Savory grazing method. Rangelands 2:234-237.

SEBER, G. A. F. 1984. Multivariate observations. New York, NY: J. Wiley and Sons. 686 p.

Soriano, A., R. J. C. León, O. E. Sala, R. S. Lavado, V. A. Deregibus, M. A. Cahuépé, 0. A. Scaglia, C. A. Velásquez, and J. H. Lemcoff. 1991. Rio de La Plata grasslands. In: R. T. Coupland [ED.]. Ecosystems of the world. Natural grasslands. Introduction and Western Hemisphere. Amsterdam: Elsevier. p 367-407.

Taylor, C. A., JR., T. D. Brooks, and N. E. GarZA. 1993. Effect of short duration and high-intensity, low frequency grazing systems on forage production and composition. Journal of Range Management 46:118-121.

Taylor, C. A., JR., M. H. Ralphs, and M. M. Kothmann. 1997. Vegetation response to increasing stocking rate under rotational stocking. Journal of Range Management 50:439-442.

Thurow, T. L., W. H. BlackBuRn, and C. A. TayloR, JR. 1988. Some vegetation responses to selected livestock grazing strategies, Edward Plateau, Texas. Journal of Range Management 41:108-114.

Weltz, M., AND M. K. Wood. 1986. Short duration grazing in central New Mexico: effects on infiltration rates. Journal of Range Management 39:365-368.

White, M. R., R. D. Pieper, G. B. Donart, and L. W. Trifaro. 1991. Vegetational response to short-duration and continuous grazing in south central New Mexico. Journal of Range Management 44:399-403.

ZaR, J. H. 1984. Biostatistical analysis. Englewood Cliffs, NJ: Prentice Hall. 718 p. 